\title{
油圧テンショナを用いた各種ボルト締結体の軸力推定手法
}

丹野 洋平*1

\section{Estimation method for axial tension of various bolted joints using hydraulic tensioner}

\author{
Yohei TANNO*1 \\ ${ }^{* 1}$ Hitachi, Ltd. Research \& Development Group \\ 832-2 Horiguchi, Hitachinaka-shi, Ibaraki 312-0034, Japan
}

Received: 7 February 2020; Revised: 5 April 2020; Accepted: 29 May 2020

\begin{abstract}
In this paper, a new method for estimating the axial tension of each bolt after the hydraulic tightening, and an appropriate structure for the hydraulic tightening have been proposed. A hydraulic tensioner is frequently used to tighten the pressure vessels by the bolted joints. The hydraulic tensioner can apply higher value and lower variation of the axial tension than the torque tightening. However, the axial tension remaining in the bolt after the hydraulic tightening is less than the initial tension by the hydraulic load, and the ratio of the residual tension to the initial tension, the effective tensile coefficient, is the most critical factor to tighten the pressure vessel securely. Some estimation methods of the ratio considering the stiffness of tightening parts have been proposed. However, there are no previous studies that verified the theory, the characteristics and the appropriate structure for the hydraulic tightening using various bolts, such as a stud bolt, a through bolt and a two-nuts bolt. In this study, we developed some new equations for estimating the effective tensile coefficient of each bolt by considering the compliance at each part of the bolted joint. Then the analysis method of the hydraulic tightening for each bolt was developed by using a finite element model simulated the joint process with the hydraulic tensioner. In addition, we evaluated the effective tensile coefficient of each bolt by the analysis and considered improvement measures of that. As a result, it was clarified that the analysis method and the equations could estimate accurately the effective tensile coefficient and the coefficient of the two-nuts bolt was the highest of the three bolt types. It was confirmed that the coefficient could be improved by locating the foot close to the bolt and reducing the diameter of the bolt-hole.
\end{abstract}

Keywords : Bolt, Tensioner, Pressure vessel, Compressor, Pump, Bolted joint, Sealing, Tightening, Hydraulic pressure

\section{1. 緒言}

高い密封性が要求される圧力容器では, 容器内部で高圧化された流体が外部に漏洩することを防止するために, 容器の締結部をボルトによって高軸力で締付けることが要求される. ボルトの締付け方法は，ナットやボルト頭 部を回転させて被締結体を締付ける方法と，油圧や熱によりボルトを軸方向に伸張させた後にナットを着座させ て被締結体を締付ける方法の 2 種類に大別される. 高軸力での締付けが要求される圧力容器では, 主に後者の方 法が適用され，その中でも油圧機械の油圧テンショナを使用した締付け方法（福岡，1997，菅野，永井，1998， 佐伯，2015）が多用されている。この締付け手順としては，油圧テンショナでボルト先端を把持し，油圧でボル 卜を軸方向に伸張させた後，ナットを被締結体に着座させ，油圧を開放することにより，被締結体を締付けるこ とができる．この締付け方法には，油圧によって簡便にボルトに高軸力を負荷でき，かつ，締結部材間の接触摩 擦による軸力のばらつきを低減できるという利点がある.

しかしながら，この締付け方法では，油圧開放後のボルトと被締結体の岡性変化や移動，変形により，締付け 完了時にボルトに残留する軸力が，油圧で負荷した初期軸力よりも低下する．すなわち，油圧テンショナによる ボルト締付け（以降，油圧締めと呼称）において，所望のボルト軸力を残留させるためには，初期軸力に対する 残留軸力の值を高精度に推定する必要がある。残留軸力を初期軸力で除算して得られる係数（以隆，有効軸力係 No.20-00036 [DOI:10.1299/transjsme.20-00036], J-STAGE Advance Publication date : 8 June, 2020

${ }^{* 1}$ 正員，（株）日立製作所 研究開発グループ 機械イノベーションセンタ（テ312-0034 茨城県ひたちなか市堀口 832-2）

E-mail of corresponding author: yohei.tanno.vp@hitachi.com 
数と呼称）に関して, 締結部材の剛性（Verein Deutscher Ingenieure, 1986, 2003，中込他，1988，Lori and Glaser, 1990) や，部材間の接触面剛性（丸井他，1993，永田他，2004，黒沢他，2009）などを考慮して推定する手法（Fukuoka, 1992, 1994, 2000, 丹野他, 2016）がいくつか報告されている. ボルトには, 植込みボルト，通しボルト，両ナッ トボルトなど様々な種類が存在し，被締結体の構造に応じて各種ボルトが使い分けられているが，各種ボルトに 対する油圧締めの理論, 特性に関する研究例や, 油圧締めに適性な構造に関寸る検討例は過去に見当たらない. これらを検討することにより，油圧締めを適用した各種締結体において，高精度な軸力管理や，高軸力での締結 が可能となると考えられる.

本研究では，植込みボルト，通しボルト，両ナットボルトの 3 種類のボルトに対して，締結体各部のコンプラ イアンスを考慮して, 有効軸力係数の各推定式を新たに提案した。 また，油圧締めにおける油圧開放前後の一連 の過程を模擬した有限要素モデルにより, 各ボルトにおいて有効軸力倸数を推定するための解析手法を構築し, 実験によりその妥当性を検証した．さらに，各ボルトの油圧締め解析を行い，各々の有効軸力係数や油圧開放前 後のコンプライアンスを解明するとともに, 有効軸力係数の向上策を提案した.

\section{2. 油圧締め原理と有効軸力係数推定式}

\section{$2 \cdot 1$ 油圧締めの手順}

植込みボルトで上下のフランジを締結する場合を例として，油圧締めの手順を説明する．図 1 に油圧テンショ ナの構造と締付け手順を示寸. 図 1(a)に示寸ように, 油圧テンショナはフート, 油圧ジャッキ, テンションロッ ドで構成され，ナットを上フランジ上部に配置した状態で，フートと油圧ジャッキを設置し，テンションロッド によりボルトを把持する，そして，図 1(b)のように，油圧ジャッキに油圧を負荷してテンションロッドを上昇さ せることで，ボルトは軸方向に伸張する．この際，ボルトには初期軸力 $F_{i}$ が発生し，ナット下面と上フランジ上 面の間には間隙が発生する，さらに，図1(c)のように，油圧を負荷した状態で，ナットを回転させて，ナット下 面を上フランジ上面に着座させる. 最後に, 図 1(d)のように, 油圧を開放することで，ボルトには初期軸力 $F_{i} よ$ り小さい残留軸力 $F_{r}$ が発生し, 締付けが完了する.

ここで，式(1)に示すように，残留軸力 $F_{r}$ を初期軸力 $F_{i}$ で除算して得られる值を有効軸力係数 $\gamma$ と定義する (Fukuoka, 1992, 1994, 2000). 有効軸力係数 $\gamma$ は, 油圧開放前後における締結部材のコンプライアンスや移動量に より導出され，これらの值を理論や解析により把握することによって, 締付け完了後の残留軸力 $F_{r}$ を推定するこ とができる（丹野他，2016）。

$$
\gamma=\frac{F_{r}}{F_{i}}
$$

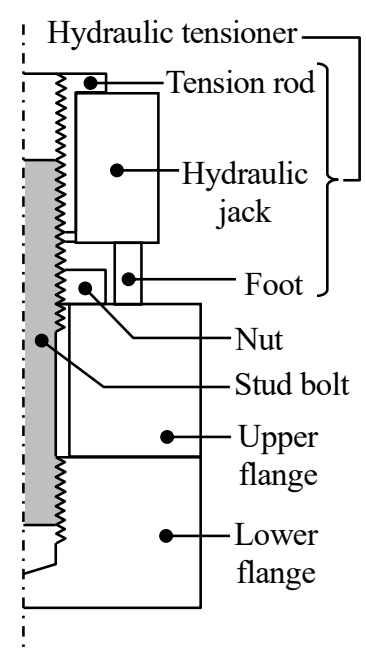

(a) Setting

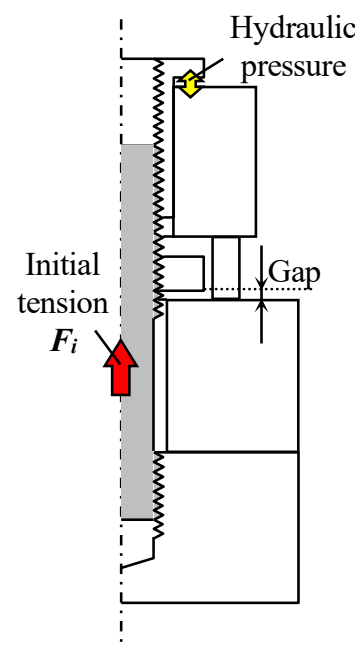

(b) Hydraulic loading

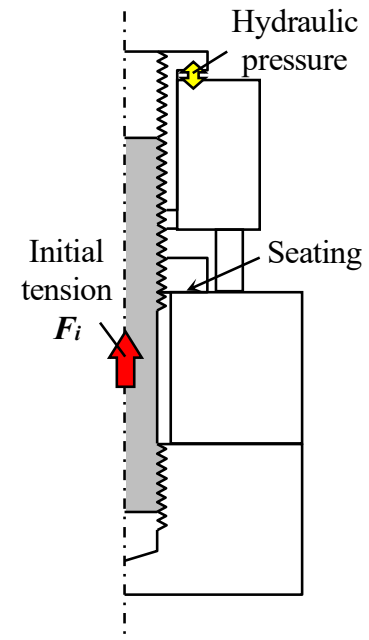

(c) Seating nut

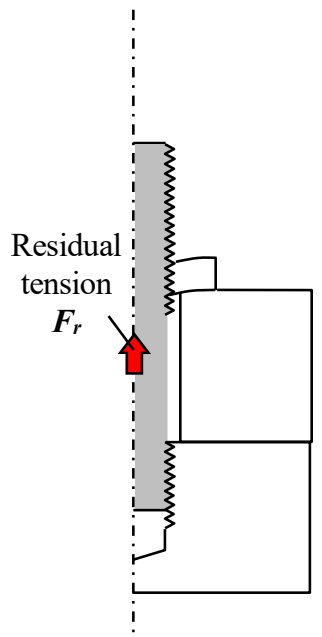

(d) After tightened

Fig.1 Structure of hydraulic tensioner and joint process. 


\section{$2 \cdot 2$ 油圧締めの締付け線図}

油圧締めの締付け線図を描いて，油圧開放前後における締結部材のコンプライアンスや移動量について検討し た. 図 2 に油圧締めの締付け線図を示す，締付け線図は，ボルト・ナットと被締結体の荷重・変位関係を表し， 図 2 では, ナット下面と上フランジ上面の変形に着目して線図を描いている. 図 2(a)は, 油圧テンショナの油圧 によりボルトに初期軸力 $F_{i}$ が発生している状態の締付け線図と, 説明図を示している. 初期軸力 $F_{i}$ でボルトが伸 張することにより，ナット下面は，ばね定数 $K_{b}{ }_{b}$ （コンプライアンス $\delta_{b}{ }_{b}$ ）の傾きで初期位置[I]から $\lambda_{b}{ }_{b}$ 変位する. また，フートにより初期軸力の反力 $F_{i}$ で上フランジが圧縮されることにより，上フランジ上面は，ば叔定数 $K^{\prime}{ }_{u f}$ (コンプライアンス $\left.\delta^{\prime}{ }_{u f}\right)$ の傾きで初期位置[1]から $\lambda^{\prime}{ }_{u f}$ 変位する. この後, ナットを着座位置[S]まで距離 $\left(\lambda^{\prime}{ }_{b}+\lambda^{\prime}{ }_{u f}\right)$ の分だけ降下させ，上フランジに着座させた後，油圧テンショナの油圧を開放する.

図 2(b)は，油圧を開放後，ボルトに残留軸力 $F_{r}$ が発生している状態を示している．油圧を開放することで，上 フランジがフートで圧縮される状態から, ナットで圧縮される状態に変化し，ボルト・ナットのばね定数が $K_{b}($ コ ンプライアンス $\delta_{b}$ ) に，かつ，上フランジのばね定数が $K_{u f}$ (コンプライアンス $\delta_{u f}$ ) に変化する. さらに，ナット 下面が上フランジ上面に接触することで，接触部周辺で締結体各部が $\lambda_{s}$ 移動し，ナット下面と上フランジ上面が 釣り合い位置[P]でバランスすることで，残留軸力 $F_{r}$ が発生する．移動量 $\lambda_{s}$ に起因するものとしては，ボルト㸚 じ山とナットねじ山が噛み合うまでにボルトが降下する量や，ナット下面と上フランジ上面の表面粗さがへたる 量，および，上フランジボルト穴近傍の表面が陥没する量が考えられる．上フランジボルト穴近傍の表面が塑性 変形せず，弾性範囲内で変形する条件においては，ボルトの降下量や表面粗さのへたり量が残留軸力に影響する が，後者のへたり量による残留軸力の低下量はおよそ1〜2\%である（丹野，成瀬，2018）.

\section{$2 \cdot 3$ 各種ボルトの有効軸力係数推定式}

各種ボルトにおける有効軸力係数の推定式について, 図 2 の締付け線図と, 締結体各部のコンプライアンスを 考慮し提案する. 図 2 で示した締付け線図の幾何学的な関係から, 有効軸力係数 $\gamma$ は, 油圧開放前後のボルト・ ナットと被締結体の各コンプライアンス $\delta^{\prime}{ }_{b}, \delta^{\prime}{ }_{u f}, \delta_{b}, \delta_{u f}$ と，移動量 $\lambda_{s}$, 初期軸力 $F_{i}$ を用いて，式(2)で導出する ことができる. 式(2)中の各コンプライアンスは各種ボルトで異なるため，初期軸力や被締結体の仕様が同一の条 件であっても，それぞれのボルトで有効軸力係数は変化すると考えられる.

$$
\gamma=\frac{\delta_{b}^{\prime}+\delta_{u f}^{\prime}}{\delta_{b}+\delta_{u f}}-\frac{\lambda_{s}}{F_{i}\left(\delta_{b}+\delta_{u f}\right)}
$$

図 3 に各種ボルト締結体のコンプライアンスを示す．図 3(a)の植込みボルトの場合, 油圧負荷時におけるボル ト・ナットのコンプライアンス $\delta^{\prime}{ }_{b}$ は，式(3)に示すように，油圧負荷時に変形するボルト非かみ合いねじ部，ボ

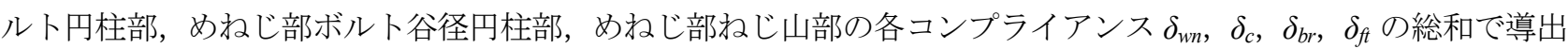
される．ボルトに油圧を負荷した状態から，ナットを着座させ油圧を開放することで，新たにボルトとナットが 噛み合い，ナット部のコンプライアンスが追加される，すなわち，油圧開放後におけるボルト・ナットのコンプ

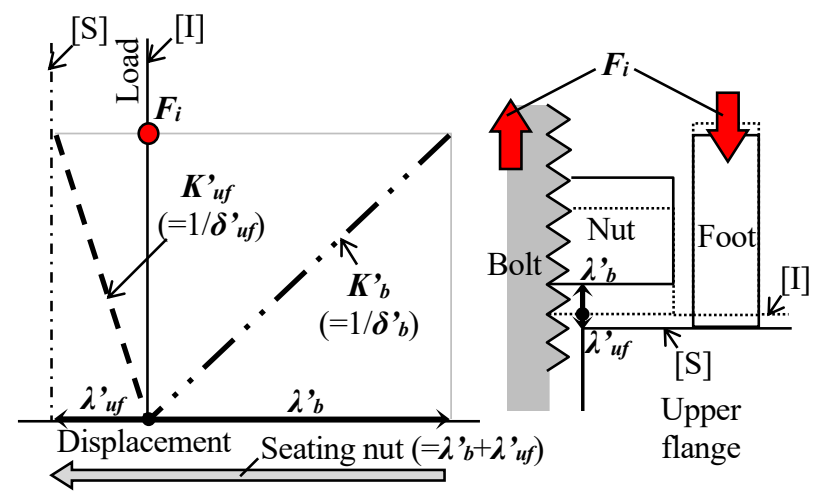

(a) Hydraulic loading and seating nut

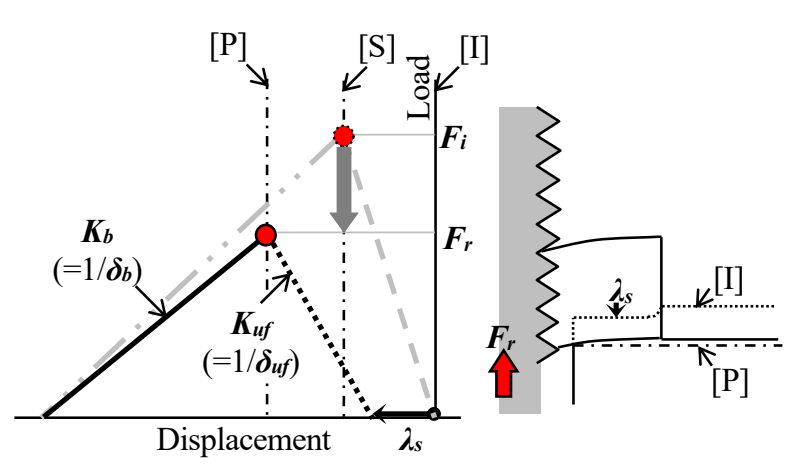

(b) After tightened

Fig.2 Joint diagram of hydraulic tightening. 
ライアンス $\delta_{b}$ は，式(4)に示すように，式(3)のコンプライアンスに，ナット部ボルト谷径円柱部と，ナット部ね じ山部の各コンプライアンス $\delta_{n r}, \delta_{n t}$ を加算することで導出される.

$$
\begin{aligned}
& \delta_{b}^{\prime}=\delta_{w n}+\delta_{c}+\delta_{b r}+\delta_{f t} \\
& \delta_{b}=\delta_{w n}+\delta_{c}+\delta_{b r}+\delta_{f t}+\delta_{n r}+\delta_{n t}
\end{aligned}
$$

図 3(b)の通しボルトの場合，下フランジにはねじ込み部が設けられていないため，油圧負荷時はボルト頭が変 形する. 寸なわち, 油圧負荷時におけるボルト・ナットのコンプライアンス $\delta^{\prime}{ }_{b}$ は, 式(5)に示すように，ボルト非 かみ合いねじ部，ボルト円柱部，ボルト頭部の各コンプライアンス $\delta_{w n}, \delta_{c}, \delta_{h}$ の総和で導出される. 油圧開放後 におけるボルト・ナットのコンプライアンス $\delta_{b}$ は, 式(6)に示すように, 式(5)のコンプライアンスに, ナット部ボ ルト谷径円柱部と, ナット部ねじ山部の各コンプライアンス $\delta_{n r}, \delta_{n t}$ を加算することで導出される. なお, 通しボ ルトの場合, ボルト頭により被締結体の底面側から変形するため, 植込みボルトと比較して, 有効締付け長さが 増加する. すなわち, 通しボルトのボルト円柱部と被締結体の各コンプライアンス $\delta_{c}, \delta_{u f f}, \delta_{u f}$ は, 植込みボルト と比較して増加する.

$$
\begin{aligned}
& \delta_{b}^{\prime}=\delta_{w n}+\delta_{c}+\delta_{h} \\
& \delta_{b}=\delta_{w n}+\delta_{c}+\delta_{h}+\delta_{n r}+\delta_{n t}
\end{aligned}
$$

図 3(c)の両ナットボルトの場合，通しボルト同様，下フランジにはねじ込み部が設けられていないため，油圧 負荷時は下ナットが変形する. 寸なわち, 油圧負荷時におけるボルト・ナットのコンプライアンス $\delta^{\prime}{ }_{b}$ は, 式(7) に示すように，ボルト非かみ合いねじ部，ボルト円柱部，下ナット部ボルト谷径円柱部，下ナット部ねじ山部の 各コンプライアンス $\delta_{w n}, \delta_{c}, \delta_{l n r}, \delta_{l n t}$ の総和で導出される. 油圧開放後におけるボルト・ナットのコンプライアン ス $\delta_{b}$ は, 式(8)に示すように, 式(7)のコンプライアンスに, 上ナット部ボルト谷径円柱部と, 上ナット部ねじ山部 の各コンプライアンス $\delta_{n r}, \delta_{n t}$ を加算することで導出される. なお, 通しボルト同様, 両ナットボルトのボルト円 柱部と被締結体の各コンプライアンス $\delta_{c}, \delta^{\prime}{ }_{u f}, \delta_{u f}$ は, 植込みボルトと比較して増加する.

$$
\begin{aligned}
& \delta_{b}^{\prime}=\delta_{w n}+\delta_{c}+\delta_{l n r}+\delta_{l n t} \\
& \delta_{b}=\delta_{w n}+\delta_{c}+\delta_{l n r}+\delta_{l n t}+\delta_{n r}+\delta_{n t}
\end{aligned}
$$

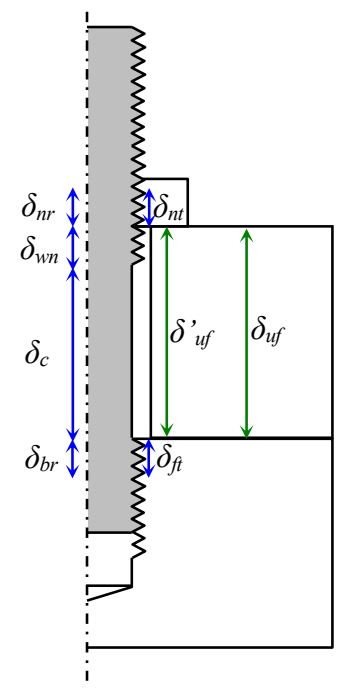

(a) Stud bolt

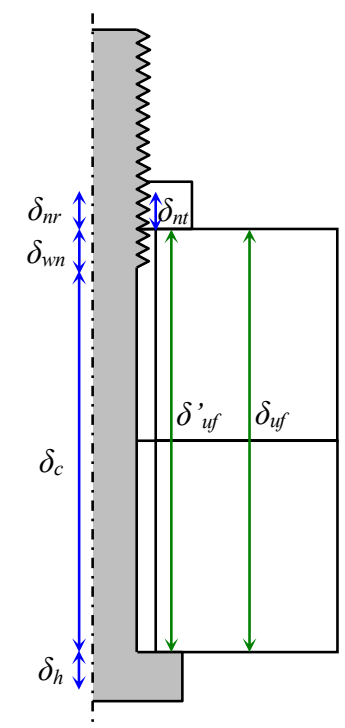

(b) Through bolt

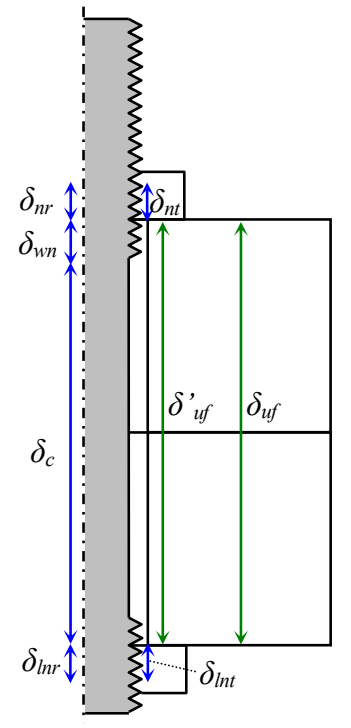

(c) Two-nuts bolt

Fig.3 Compliance of each bolted joint. 
式(3)〜(8)を式(2)に代入し，かつ，式(2)中の $\lambda_{s} / F_{i}$ を移動量に関するコンプライアンス $\delta_{s}$ と定義することで，植 込みボルト, 通しボルト, 両ナットボルトの各有効軸力係数 $\gamma_{s}, \gamma_{t}, \gamma_{n}$ の推定式は, それぞれ式(9), (10), (11)で 表される.これらの式に, 解析や理論で導出した各コンプライアンスの数值を代入することにより, 各ボルトの 有効軸力係数を推定することが可能となる.

$$
\begin{aligned}
& \gamma_{s}=\frac{\delta_{w n}+\delta_{c}+\delta_{b r}+\delta_{f t}+\delta_{u f}^{\prime}-\delta_{s}}{\delta_{w n}+\delta_{c}+\delta_{b r}+\delta_{f t}+\delta_{n r}+\delta_{n t}+\delta_{u f}} \\
& \gamma_{t}=\frac{\delta_{w n}+\delta_{c}+\delta_{h}+\delta_{u f}^{\prime}-\delta_{s}}{\delta_{w n}+\delta_{c}+\delta_{h}+\delta_{n r}+\delta_{n t}+\delta_{u f}} \\
& \gamma_{n}=\frac{\delta_{w n}+\delta_{c}+\delta_{l n r}+\delta_{l n t}+\delta_{u f}^{\prime}-\delta_{s}}{\delta_{w n}+\delta_{c}+\delta_{l n r}+\delta_{l n t}+\delta_{n r}+\delta_{n t}+\delta_{u f}}
\end{aligned}
$$

\section{3. 油圧締めの有限要素解析手法}

\section{$3 \cdot 1$ 解析モデル}

油圧締めにおける油圧開放前後の一連の過程を模擬した有限要素モデルにより, 各ボルトにおいて有効軸力係 数を推定するための解析手法を構築した. 図 4 に油圧締めの解析モデルを示す. 図 4(a)には, 油圧を負荷した状 態を再現したモデル, 図 4(b)には, ナットを着座後, 油圧を開放して油圧締めが完了した状態を再現したモデル を示している. なお, 図 4 では, 植込みボルトの場合の例を示しており, 通しボルトや両ナットボルトの場合は, ボルト・ナットや下フランジのモデル形状を図 3(b)(c)に示した形態に変化させている. 図 4(a)に示すように, モ デルは, ボルト, ナット, フート, 上フランジ，下フランジを，それぞれボルト中心を軸とした 2 次元軸対称要 素でモデル化したものである. なお，各部材の仕様は，次節で後述する実験で用いたものと同様とし，ボルト中 心にはひずみゲージ配線用の穴も模擬している. 各部材表面の粗さ形状に関しては, モデル上は省略しているが, 表面粗さのへたりの影響は後述する接触条件で考慮している．ボルト，ナット，下フランジのねじ山形状に関し ても，モデル上は省略し，各部材のねじ噛合い部は円筒面上で節点共有させている.

各部材はそれぞれ鋼材で，ボルト，ナット，上下フランジは縦弾性係数 $206 \mathrm{GPa}$ ，フートは側面穴部の断面積 減少分を考慮して縦弾性係数 $156 \mathrm{GPa}$ の弾性体とした. ねじ噛合い部の剛性については, VDI 2230 (Verein Deutscher Ingenieure, 2003）に記載されているコンプライアンスに一致するように，ボルト外周要素 1 列分の縦弾性係数を 低下させた. 具体的には, 植込みボルト, 通しボルト, 両ナットボルトにおけるナットのねじ噛合い部は $11.5 \mathrm{GPa}$, 植込みボルトにおける下フランジのねじ込み部は $10 \mathrm{GPa}$ にそれぞれ縦弾性係数を設定した. ボルトには, 初期軸

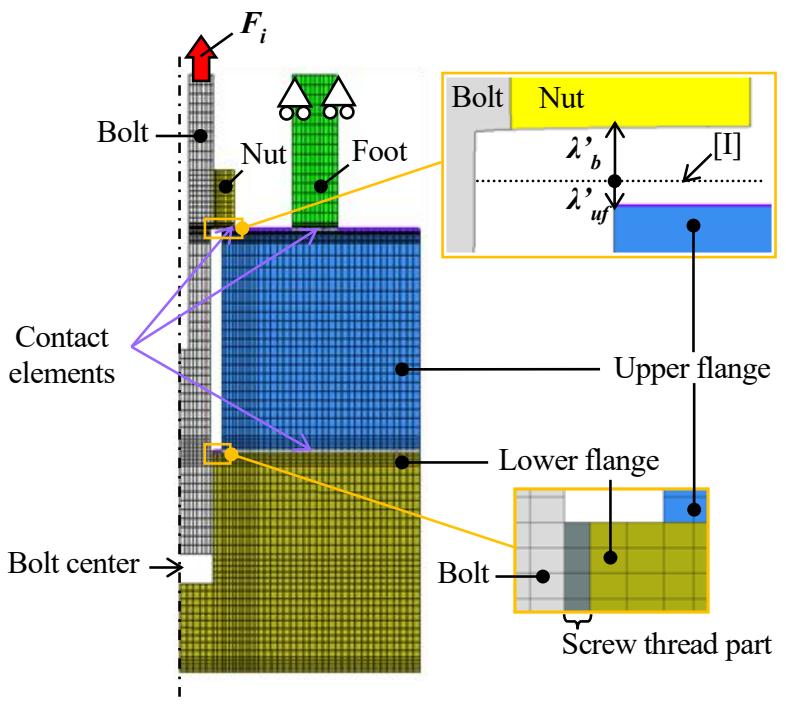

(a) Hydraulic loading

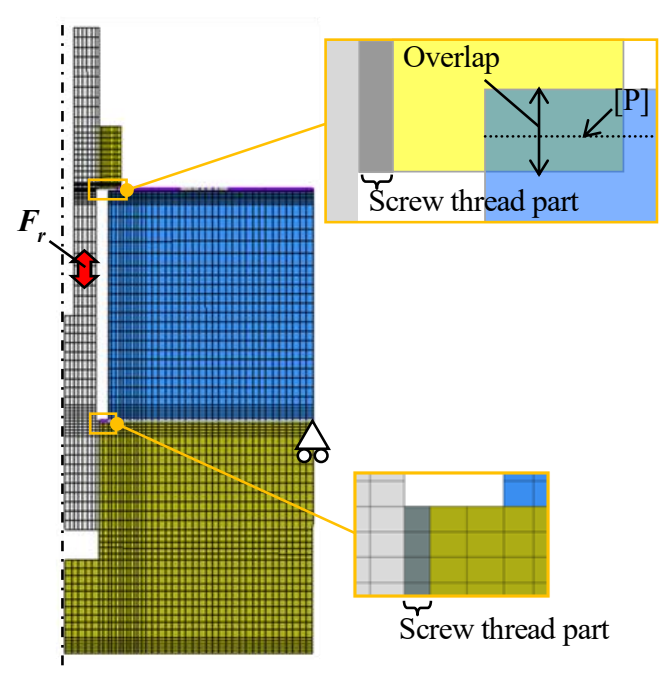

(b) After tightened

Fig.4 Analysis model for hydraulic tightening. 
カ $F_{i}$ を定義し，フート上面には上下方向の拘束を定義した．また，ナットや上下フランジの接触部には，接触要 素を定義した．なお，各部材のメッシュサイズは $0.4 \sim 4 \mathrm{~mm}$ としているが，その半分のメッシュサイズとした場 合においても解析結果に差はなく，解析結果のメッシュサイズ依存性が微小であることも確認した. 図 4(a)のモ デルを用いた解析結果から, 油圧を負荷した際の初期位置[I]からのナット下面の変位 $\lambda_{b}{ }_{b}$ と, 上フランジ上面の変

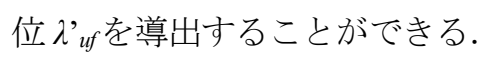

図 4(b)の油圧開放時のモデルでは，図 4(a)のモデルからフートを消去しており，フートやボルトに設定してい た初期軸力も除荷している．また，ナット下面の変位 $\lambda^{\prime}{ }_{b}$ と上フランジ上面の変位 $\lambda^{\prime}{ }_{u f}$ の和から, 締結体各部の移 動量 $\lambda_{s}$ を差し引いた距離 $\left(\lambda^{\prime}{ }_{b}+\lambda^{\prime}{ }_{u f} \lambda_{s}\right)$ の分だけ，ナット下面と上フランジ上面をオーバーラップさせ，ナットの着 座と, 締結体各部の移動を模擬している. ナット下面と上フランジ上面には接触要素を定義しているため, 本モ デルで解析を実行することにより，ナット下面が押し上げられるとともに，フランジ上面が押し下げられ，双方 は釣り合い位置[P]でバランス寸る. これにより, ボルトは軸方向に伸長し, ボルトには残留軸力 $F_{r}$ が発生する. 図 4(b)の残留軸力 $F_{r}$ を, 図 4(a)の初期軸力 $F_{i}$ で除算することにより, 有効軸力係数が導出される.

\section{$3 \cdot 2$ 解析精度検証}

前節で示した解析モデルおよび手法の妥当性を検証するために，植込みボルトを例に，油圧締め実験を行い， 実験結果と解析結果を比較した．各部材の寸法については，ボルトは M24，ナット外径（丸ナット）は $36 \mathrm{mm,}$ ナット高さは $20 \mathrm{~mm}$ ，下フランジ厚さは $75 \mathrm{~mm}$ ，ナット表面粗さは $6.3 \mu \mathrm{m}$ とし，上フランジ厚さを $50,75,100$ $\mathrm{mm}$ ，上フランジ表面粗さを $0.2 ， 3.2 ， 25 \mu \mathrm{m}$ に変化させた．実験では，まず油圧テンショナにより，ボルトに約 $150 \mathrm{kN}$ の軸力が発生するまで徐々に油圧を負荷した. 次に, その状態で数秒間保持した後, 軸力が安定した段階 で，その值を初期軸力として記録した，さらに，ナットを締付け，上フランジに着座させ，油圧を開放し，数秒

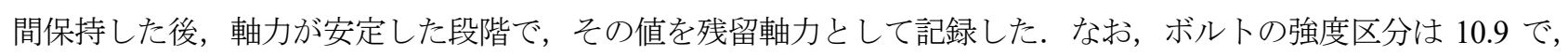
初期軸力の $150 \mathrm{kN}$ につては, ナット座面の限界面圧を考慮して設定した（丹野，成瀬，2018）。ナットの締付 け方法に関しては, 各種方法を試行した結果, 残留軸力の結果に最もばらつきが小さかった手締め（ばらつき $4 \%$ 以内）を選択した。実験は同じ条件で 2 回ずつ実施したが，2 回目の実験時はナットと上フランジのみ新しい試 験体に交換し，上記同様の流れで計測を行った．また，解析については，ANSYS® ver.2019を用いた．解析モデ

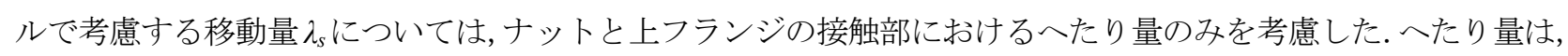
酒井らの実験結果（酒井，2009）に基づき，ナット表面粗さと上フランジ表面粗さの和を 0.3 倍した值とした.

図 5 に実験結果と解析結果の比較を示寸. 図 5(a)には上フランジ厚さを変化させた結果, 図 5(b)にはへたり量 （上フランジ表面粗さ）を変化させた結果を示している. なお, 図 5(a)では上フランジ表面粗さを $3.2 \mu \mathrm{m}$, 図 $5(\mathrm{~b})$ では上フランジ厚さを $75 \mathrm{~mm}$ に固定している. また, 実験結果は, 2 回の結果の平均值である. 図 5(a)の結果か ら, 実験結果（ロプロット）については, 上フランジ厚さが増加するほど, 有効軸力係数は 1 に近付いている. これは，上フランジが厚くなることで，ボルトも長くなり，2・3 節で述べた有効軸力係数推定式 (式(9) (11)

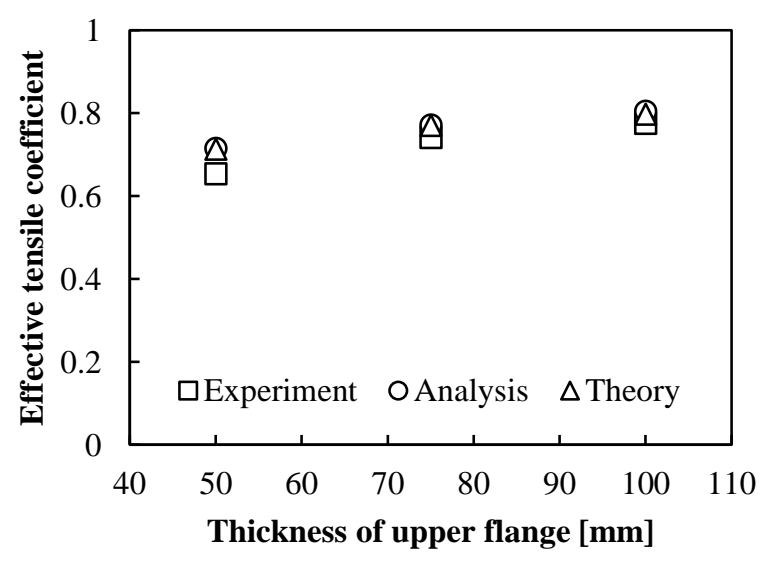

(a) Results of each thickness of upper flange

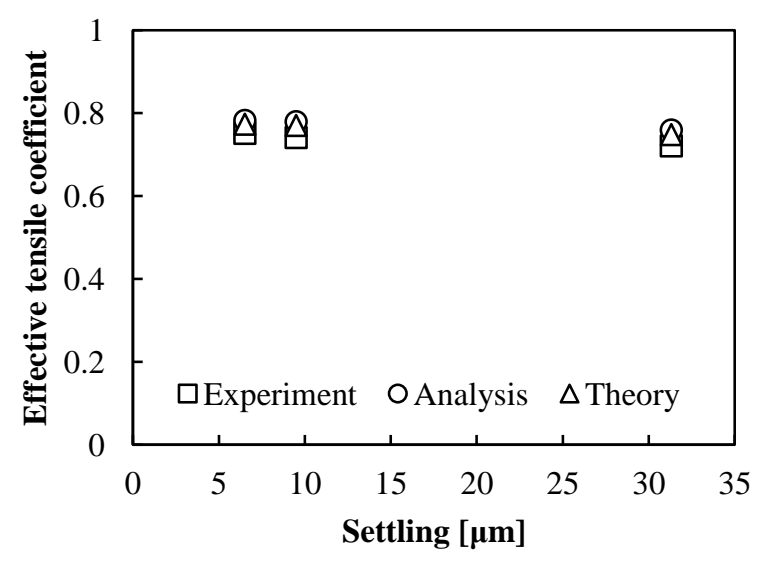

(b) Results of each settling

Fig.5 Comparison between experimental results and analysis results. The trends of experimental results and analysis results are almost consistent, and the error of estimation are 4 to $9 \%$. 
における各コンプライアンス $\delta_{c}, \delta_{u f}^{\prime}, \delta_{u f}$ が増加し, 推定式の分子と分母がともに増加し, 両者の比が 1 に近付く ためである. 実験結果に対して解析結果（○プロット）の傾向は概ね一致しており，その推定誤差は 4 9\%とな った. 図 5(b)については, 実験結果は, へたり量が増加するほど有効軸力係数は微減している. これは, へたり 量が増加することで, 有効軸力係数推定式における移動量に関するコンプライアンス $\delta_{s}$ 染微増し, 推定式の分子 が微减するためである. 実験結果に対して解析結果の傾向は概ね一致しており, その推定誤差は 4 〜 $5 \%$ とった.

図 5 には，推定式(9)功計算した理論結果（メプロット）も載せている．推定式の各コンプライアンスの值に ついては，4・1 節の図 7 にて後述するが，ボルト円柱部は円柱部外周上の軸方向変形量，フランジ部はボルト穴 周上の高さ方向変形量，ボルト頭部は頭部座面がボルト穴内に沈み込む変形量，ねじ込み部およびナット部はボ ルト外周要素 1 列分（ねじ山部）の軸方向変形量を，それぞれ初期軸力（油圧負荷時）や残留軸力 (油圧開放時) で除算することにより算出した. 図 5 に示すように, 推定式(9)から計算した植込みボルトの有効軸力係数の理論 結果は, 解析結果と約 $1 \%$ 範囲内で一致することを確認した. また, 通しボルトや両ナットボルトの推定式(10), (11)に関しても，4・1 節の図 7 で後述する各コンプライアンスを代入して計算した理論結果が, 図 6 で後述する 解析結果と約 $1 \%$ 範囲内で一致することを確認した.

なお，図 5 において，解析結果よりも実験結果が全体的に小さくなっているが，これは実験時のナットの着座 を手締めで行ったことによる影響と考えられる，手締めでは，ナットとボルトが完全に噛み合わず，油圧開放時 に，噛み合うまでの距離分，ボルトが降下していた可能性がある．実験に用いたボルトとナットの公差等級は $6 \mathrm{H} / 6 \mathrm{~g}$ であり，お放じとめねじのボルト軸方向の間隙が，油圧開放前に数十 $\mu \mathrm{m}$ あった可能性がある. 今回の実 験条件の場合では，ボルトの降下量が約 $15 \mu \mathrm{m}$ あったと仮定すれば，有効軸力係数は約 $5 \%$ 低下する. なお，解 析においては，このボルトの降下量を図 4(b)のオーバーラップ量の設定で考慮することにより，ボルト降下によ る有効軸力係数の低下も再現することができる．また，ナットと上フランジの接触部が塑性変形し，座面陷没が 発生する場合は, 解析モデルを弾塑性体として定義することで, その影響を考慮することができる. 以上の通り， 前節で示した解析モデルおよび手法を用いることにより, 精度良く有効軸力係数が推定できることを確認した.

\section{4. 各種ボルト締結体の軸力評価}

\section{$4 \cdot 1$ 各種ボルトの有効軸力係数とコンプライアンス}

前章で示した解析手法を用いて, 植込みボルト, 通しボルト, 両ナットボルトの 3 種類のボルトに対して油圧 締め解析を行い, 各々の有効軸力係数や油圧開放前後のコンプライアンスを評価した. 各部材の寸法については,

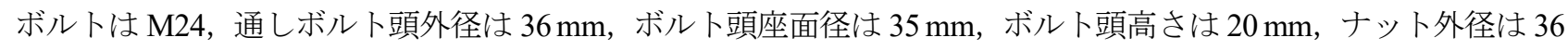
$\mathrm{mm}$ ，ナット高さは $20 \mathrm{~mm}$ ，上フランジ厚さは $75 \mathrm{~mm}$, 下フランジ厚さは $75 \mathrm{~mm}$, ナット表面粗さは $6.3 \mu \mathrm{m}$, 上 フランジ表面粗さは $3.2 \mu \mathrm{m}$ とした。 また, 油圧で負荷する初期軸力は $150 \mathrm{kN}$ とした.

図 6 に各ボルトにおける油圧締付け後の応力コンター図を示す．本図は，各部材に発生しているボルト軸方向 の応力分布で，(a)には植込みボルト，(b)には通しボルト，(c)には両ナットボルトの結果を示している. 各ボルト とも，ボルトに発生した残留軸力により，上下フランジ内にはナットやボルト頭の座面から圧縮場が広がってい ることが確認できる. ナット座面の反力からボルトの残留軸力を導出した結果, 植込みボルトは $117 \mathrm{kN}$, 通しボ ルトは $129 \mathrm{kN}$, 両ナットボルトは $130 \mathrm{kN}$ となった。この残留軸力を初期軸力 $150 \mathrm{kN}$ で除算した有効軸力係数 は, 植込みボルトが 0.780 , 通しボルトが 0.859 , 両ナットボルトが 0.866 となった. すなわち, 同一寸法の被締 結体を各ボルトで油圧締めした場合, 両ナットボルトの有効軸力係数が最も高くなり, 被締結体を強固に締結で きることが分かった.

図 7 に締結体各部のコンプライアンスを示す. 本図は, 式(9)〜(11)に示した有効軸力係数の推定式における分 子と分母の各コンプライアンスを変位解析結果から算出した結果で, (a)には植込みボルト，(b)には通しボルト， (c)には両ナットボルトの結果を示している. なお, 解析上, ボルトは円柱形状でボルト非かみ合いるじ部の長さ は 0 としており, 図 7 において, ボルト非か夕合いねじ部のコンプライアンス $\delta_{w n} も 0$ となる. また, 各部移動 量としては，ナットとフランジの接触部におけるへたり量を考慮しており，酒井らの実験結果（酒井，2009）か ら導出したへたり量 $2.9 \mu \mathrm{m}$ を初期軸力 $150 \mathrm{kN}$ で除算することにより, 移動量に関するコンプライアンス $\delta_{s}$ を導 
出した. 図 7 の結果から, 表面粗さのへたり量によるコンプライアンス $\delta_{s}$ はその他のコンプライアンスと比較し て微小であることが分かる.

図 7(a)の植込みボルトの場合，式(9)で示したように，推定式の分子は，油圧負荷時に変形するボルト非かみ合 いねじ部，ボルト円柱部，めねじ部ボルト谷径円柱部，めねじ部ねじ山部，および，フランジの各コンプライア ンス $\delta_{w n}, \delta_{c}, \delta_{b r}, \delta_{f t}, \delta_{u f}$ の総和から, 各部移動量に関するコンプライアンス $\delta_{s}$ を差し引くことで導出される. また，推定式の分母は，油圧開放時に変形するボルト非かみ合い㸚じ部，ボルト円柱部，めねじ部ボルト谷径円 柱部，めねじ部㸚じ山部，ナット部ボルト谷径円柱部，ナット部ねじ山部，および，フランジの各コンプライア ンス $\delta_{w n}, \delta_{c}, \delta_{b r}, \delta_{f t}, \delta_{n r}, \delta_{n t}, \delta_{u f}$ の総和である. 図7(a)の結果から, 植込みボルトにおいて, 有効軸力係数に主 に影響しているコンプライアンスとしては，ボルト $\delta_{c}$, ねじ込み部 $\left(\delta_{b r}+\delta_{f t}\right)$, フランジ $\delta^{(()}{ }_{u f}$, ナット $\left(\delta_{n r}+\delta_{n t}\right)$ が挙げ

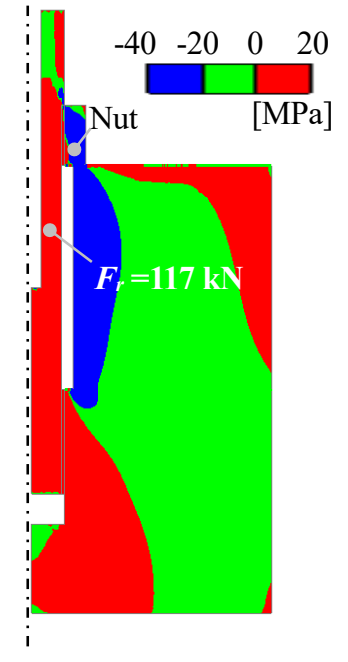

(a) Stud bolt

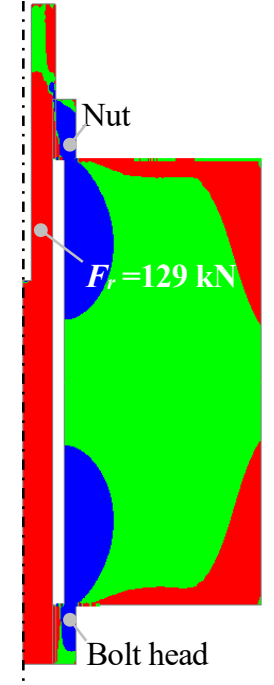

(b) Through bolt

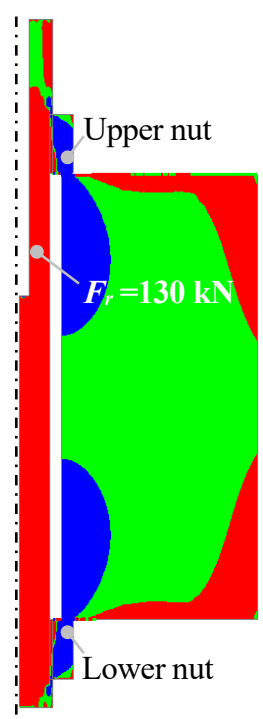

(c) Two-nuts bolt

Fig.6 Stress contour figure of each bolt after hydraulic tightening. The residual tension of two-nut bolt is the highest in the three bolt types.

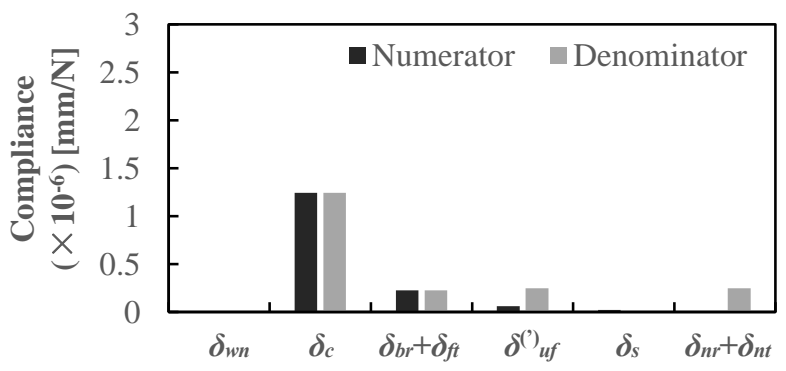

(a) Stud bolt

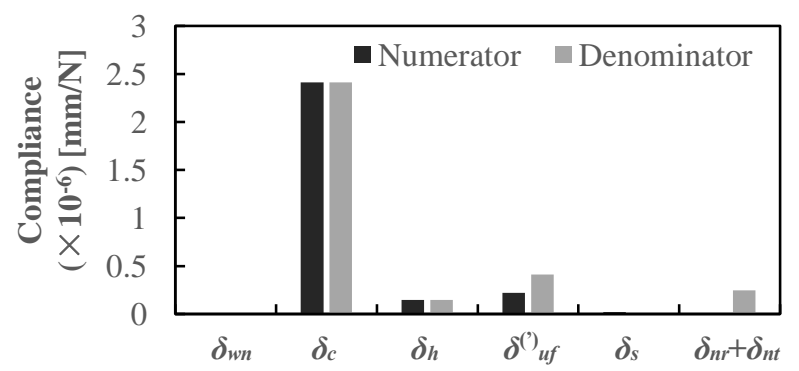

(b) Through bolt

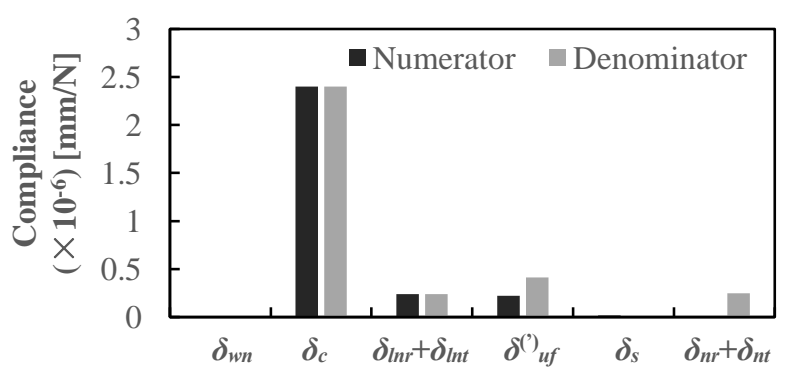

(c) Two-nuts bolt

Fig.7 Compliance of each part in bolted joint. Total compliance at hydraulic loading of two-nuts bolt is 1.88 times, and total compliance after hydraulic tightening is 1.68 times compared to stud bolt. As a result, the effective tensile coefficient of two-nuts bolt is the highest in the three bolt types. 
られ，ボルトのコンプライアンス $\delta_{c}$ が最大となる. フランジのコンプライアンスについては, 油圧開放前後で, 油圧テンショナのフートによる締付けから, ナットによる締付けに遷移するため, 油圧負荷時のコンプライアン ス $\delta_{u f}{ }_{u f}$ と油圧開放後のコンプライアンス $\delta_{u f}$ は異なる. 一般的にフートはボルトから径方向に離れた位置に設置さ れるため, フートによる締付けでは, ボルト穴近傍のフランジの変形, 寸なわちコンプライアンス $\delta_{u f}{ }_{u f}$ は微小と なる.ナットによる締付けでは, ボルト穴近傍がナット座面で直接圧縮されるため, ボルト穴近傍の変形が増加 し, 油圧負荷時のコンプライアンス $\delta_{u f}{ }_{u f}$ りも油圧開放後のコンプライアンス $\delta_{u f}$ が増加する. また, 油圧開放後 は，ナットのコンプライアンス $\left(\delta_{n r}+\delta_{n t}\right)$ が新たに加算される.

図 7(b)の通しボルトの場合, 式(10)で示したように, 推定式の分子は, 油圧負荷時に変形するボルト非かみ合い ねじ部，ボルト円柱部，ボルト頭部，および，フランジの各コンプライアンス $\delta_{w n}, \delta_{c}, \delta_{h}, \delta{ }_{u f}$ の総和から, 各部 移動量に関するコンプライアンス $\delta_{s}$ を差し引くことで導出される. また, 推定式の分母は, 油圧開放時に変形す るボルト非かみ合いるじ部，ボルト円柱部，ボルト頭部，ナット部ボルト谷径円柱部，ナット部ねじ山部，およ び，フランジの各コンプライアンス $\delta_{w n}, \delta_{c}, \delta_{h}, \delta_{n}, \delta_{n t}, \delta_{u f}$ の総和である. 図 7(b)の結果から, 通しボルトにお いても, 植込みボルト同様, ボルトのコンプライアンス $\delta_{c}$ が最大となる. 植込みボルトと比較して, 通しボルト は締結体の有効締付け長さが増加するため, ボルトのコンプライアンス $\delta_{c}$ やフランジのコンプライアンス $\delta^{\left({ }^{()}\right.}{ }_{u f}$ が 図 7(a)に示寸結果よりも増加している. また，植込みボルトのねじ込み部と比較して，通しボルトのボルト頭部 は剛性が高いため, 図 7(a)のねじ込久部のコンプライアンス $\left(\delta_{b r}+\delta_{f t}\right)$ よりも, 図 7(b)のボルト頭部のコンプライア ンス $\delta_{h}$ は微减している. 油圧開放後にフランジのコンプライアンス $\delta_{u f}$ が増加することや, ナットのコンプライ アンス $\left(\delta_{n r}+\delta_{n t}\right)$ が加算されることは，植込みボルトと同様である.

図 7(c)の両ナットボルトの場合, 式(11)で示したように, 推定式の分子は, 油圧負荷時に変形するボルト非か夕 合いねじ部，ボルト円柱部，下ナット部ボルト谷径円柱部，下ナット部ねじ山部，および，フランジの各コンプ ライアンス $\delta_{w n}, \delta_{c}, \delta_{l n}, \quad \delta_{l n t}, \delta_{u f}{ }_{u f}$ の総和から, 各部移動量に関するコンプライアンス $\delta_{s}$ を差し引くことで導出さ れる. また, 推定式の分母は, 油圧開放時に変形するボルト非か夕合いねじ部, ボルト円柱部, 下ナット部ボル 卜谷径円柱部，下ナット部衩じ山部，上ナット部ボルト谷径円柱部，上ナット部ねじ山部，および，フランジの 各コンプライアンス $\delta_{w n}, \delta_{c}, \delta_{l n r}, \delta_{l n t}, \delta_{n r}, \delta_{n t}, \delta_{u f}$ の総和である. 図 7(c)の結果から，両ナットボルトにおいて も, ボルトのコンプライアンス $\delta_{c}$ が最大となる. また, 通しボルト同様, 両ナットボルトによる被締結体の有効 締付け長さは，植込みボルトよりも増加するため, ボルトのコンプライアンス $\delta_{c}$ やフランジのコンプライアンス $\delta^{\left({ }^{()}\right.}{ }_{u f}$ が図 7(a)に示寸結果よりも増加している. また, 通しボルトのボルト頭部と比較して, 両ナットボルトの下 ナットかみ合い部は剛性が低いため, 図 7(b)のボルト頭部のコンプライアンス $\delta_{h}$ よりも, 図 7(c)の下ナットかみ 合い部のコンプライアンス $\left(\delta_{l n r}+\delta_{l n t}\right)$ は微増している. 油圧開放後にフランジのコンプライアンス $\delta_{l f}$ が増加するこ とや，ナットのコンプライアンス $\left(\delta_{n r}+\delta_{n t}\right)$ が加算されることは，植込みボルトと同様である.

以上の結果から, 通しボルトと両ナットボルトは, 植込みボルトよりも締結体の有効締付け長さが長く, 有効 軸力係数推定式の分子と分母の双方にあるボルトのコンプライアンス $\delta_{c}$ やフランジのコンプライアンス $\delta^{\left({ }^{()}{ }_{u f} \text { が }\right.}$ 増加することで, 分子と分母の比が 1 に近付き, 有効軸力係数が向上することが分かった. また, 両ナットボル トは，下ナットかみ合い部のコンプライアンスが通しボルトのボルト頭部のコンプライアンスよりも高いため, 有効軸力係数推定式の分子と分母の比がさらに 1 に近付く. 植込みボルトと比較して, 両ナットボルトにおける 油圧負荷時のコンプライアンス合計值（推定式分子）は 1.88 倍, 油圧開放時のコンプライアンス合計值（推定式 分母） は 1.68 倍となった. 結果として，3 種類のボルトの中では, 両ナットボルトの有効軸力係数が最も高くな ることを確認した.

\section{$4 \cdot 2$ 有効軸力係数向上策の検討}

油圧締めにおいて被締結体を強固に締結寸るためには, 有効軸力係数を増加させ 1 に近付ける必要がある. 式 (9)〜(11)に示した有効軸力係数の推定式や, 前節で示した締結体各部のコンプライアンスの評価結果から, 有効 軸力係数の向上策を検討した. 有効軸力係数を向上させるためには, 推定式の分子と分母を双方増加させること や，分子のみ増加させること，あるいは，分母のみ減少させることが必要となる. 分子と分母を双方増加させる 手段としては，前節で示したように，植込みボルトを通しボルトや両ナットボルトに変更する方法がある．これ

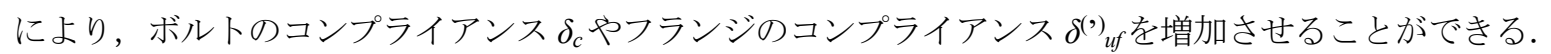


推定式の分子のみ増加させる手段としては，図 5(b)で示したように，接触部のへたり量（表面粗さ）を小さく する方法がある．これにより，締結体各部の移動量に関するコンプライアンス $\delta_{s}$ を低減させることができ，例え ばへたり量を $9.4 \mu \mathrm{m}$ から $2.9 \mu \mathrm{m}$ に低減することにより, 有効軸力係数は約 $2 \%$ 向上寸る（丹野, 成瀬, 2018). また，油圧負荷時のフランジコンプライアンス $\delta_{u f}^{\prime}$ を増加させることも有効である. その手段として例えば，油 圧テンショナのフートの位置をボルトに近接させることが考えられる. 前述の通り，一般的にフートはボルトか ら径方向に離れた位置に設置されるため, 油圧負荷時のフートによる締付けでは, ボルト穴近傍のフランジの変 形，すなわちコンプライアンス $\delta_{u f}{ }_{u f}$ は微小となる．フートをボルトに近付けることで，ボルト穴近傍のフランジ 変形を増加させることができ，コンプライアンス $\delta^{\prime}{ }_{u f}$ も増加すると考えられる. 推定式の分母のみ減少させるに は, 油圧開放時に変形寸るナットのコンプライアンス $\left(\delta_{n r}+\delta_{n t}\right)$ を低減させることが有効である. その手段としては, 例えば，上フランジのボルト穴径を縮小させることが考えられる．ボルト穴径を縮小させることで，油圧開放時 にナットがボルト穴内に沈み込む変形を抑制させることができ，コンプライアンス $\left(\delta_{n r}+\delta_{n t}\right)$ も低減すると考えられ る.

上記のフートをボルトに近接させる構造と，ボルト穴径を縮小させる構造の効果を検証するために，各々の構 造で油圧締め解析を行った. 図 8 にフート位置の効果を示寸. 本図は, 両ナットボルトの油圧負荷時における変 形図（変位 10 倍拡大図示）に軸方向応力コンターを載せた図である. 図 8(a)は，図 6(c)で解析した構造と同一の 構造で, フート位置が通常の位置の場合の例であり, ナット外径 $d_{n}(36 \mathrm{~mm})$ とフート内径 $d_{f}(75 \mathrm{~mm})$ の比 $d_{n} / d_{f}$ は 0.48 である. 図 8(b)は，フートを丸ナットに近接させた場合の例で，ナット外径 $d_{n}(36 \mathrm{~mm})$ とフート内径 $d_{f}$

$(37 \mathrm{~mm})$ の比 $d_{n} / d_{f}$ は 0.97 である. 両構造の解析結果から, ナット下面と上フランジ上面の間の間隙量を導出し た結果，図 8(a)が $0.456 \mathrm{~mm}$ ，(b)が $0.461 \mathrm{~mm}$ となり，フートをボルトに近接させることで，ボルト穴近傍のフラ ンジ変形，すなわちコンプライアンス $\delta^{\prime}{ }_{u f}$ を増加できることが分かった．両構造において，油圧開放後の残留軸 力から有効軸力係数を導出した結果, 図 $8(\mathrm{a})$ が 0.866 , (b)が 0.875 となり, フートをボルトに近接させることで有 効軸力係数が約 $1 \%$ 向上した.

図 9 にボルト穴径の効果を示す．本図は，両ナットボルトの油圧開放時における変形図（変位 10 倍拡大図示） に軸方向応力コンターを載せた図である. 図 9(a)は, 図 6(c)で解析した構造と同一の構造で, ボルト穴の等級が 3

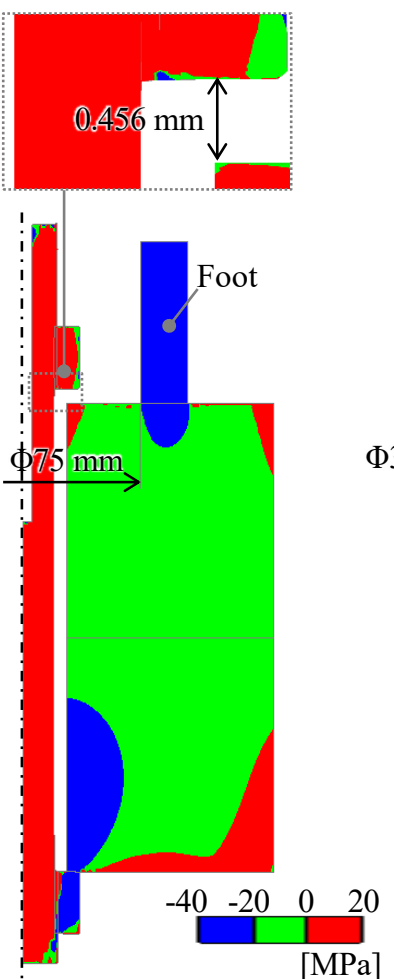

(a) $d_{n} / d_{f}=0.48$
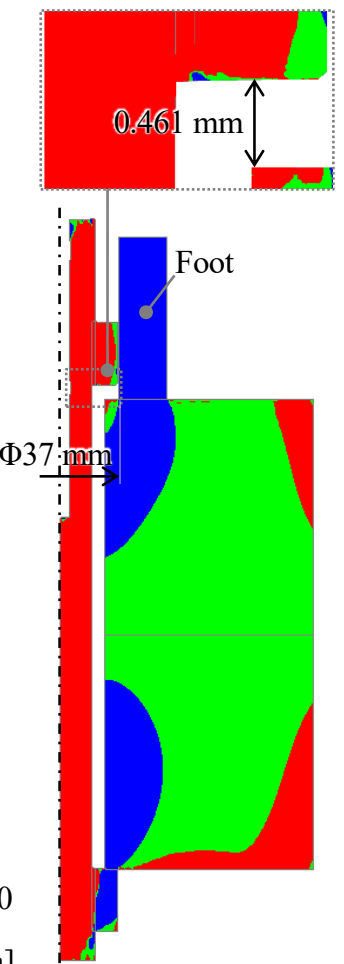

(b) $d_{n} / d_{f}=0.97$

Fig.8 Effect of foot position. The effective tensile coefficient is improved by locating the foot close to the bolt.

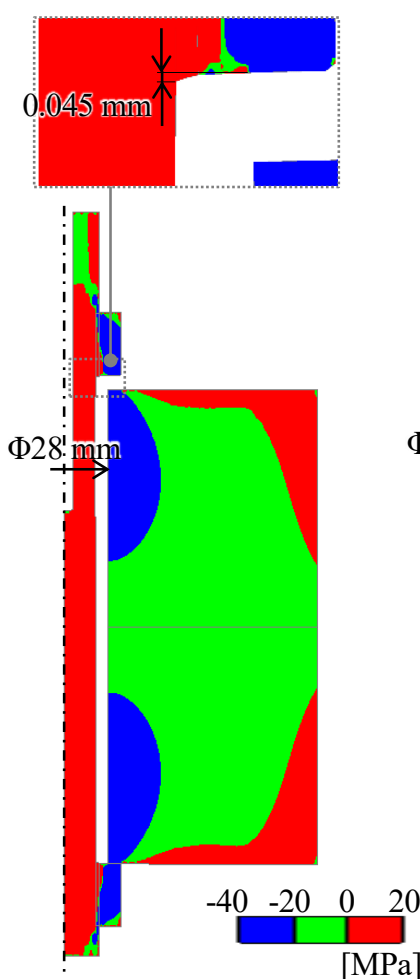

(a) $3^{\text {rd }}$ grade
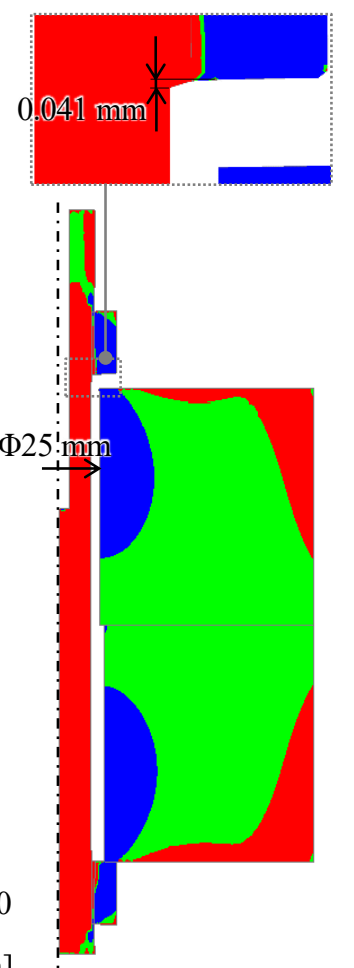

(b) $1^{\text {st }}$ grade
Fig.9 Effect of bolt-hole diameter. The effective tensile coefficient is improved by reducing the diameter. 
級で穴径は $28 \mathrm{~mm}$ である. 図 9(b)は，ボルト穴の等級が 1 級で穴径は $25 \mathrm{~mm}$ である. なお，解析モデルに設定し たオフセット条件により，図 9 ではナットとフランジの間が離れて表示されているが，ナット下面と上フランジ 上面は接触している状態である.両構造の解析結果から,ナットがボルト穴内に沈み込む変形量を導出した結果, 図 9(a)が $0.045 \mathrm{mm，(b)が} 0.041 \mathrm{~mm}$ となり，ボルト穴径を縮小させることで，油圧開放後のナットの変形，すな わちコンプライアンス $\left(\delta_{n r}+\delta_{n t}\right)$ を低減できることが分かった. 両構造において, 有効軸力係数を導出した結果, 図 9(a)が 0.866, (b)が 0.874 となり, ボルト穴径を縮小させることで有効軸力係数が約 $1 \%$ 向上した.

上記結果から，植込みボルトで油圧締めした場合と比較すると，両ナットボルトに変更するとともに，フート をボルト穴に近接させ，かっ，ボルト穴を縮小することで，有効軸力係数は約 $13 \%$ 向上できることが分かった.

\section{5. 結 言}

油圧テンショナを用いたボルト締付けでは，締付け完了時にボルトに残留する軸力が，油圧で負荷した初期軸 力よりも低下寸る，油圧締めを適用した各種締結体において，高精度に軸力を管理するためには，残留軸力を推 定する汎用的手法が必要となる，また，より強固に締結するためには，締結体各部の変形を詳細に分析し，油圧 締めに適性な構造を見出す必要がある. 本研究では, 各種ボルトを適用した締結体に対して, 残留軸力を初期軸 力で除算した有効軸力係数を推定するための各式や解析手法を構築するとともに，各種締結体のコンプライアン スを分析し，有効軸力係数の向上策を提案した．以下に結論をまとめる.

（1）油圧負荷時と開放時における締付け線図と締結体各部のコンプライアンスを検討し，植込みボルト，通しボ ルト，両ナットボルトで油圧締めした場合の有効軸力係数の各推定式を新たに提案した．また，油圧開放前 後の一連の締付け過程を模擬した有限要素モデルにより, 各種ボルトにおいて有効軸力係数を推定するため の解析手法を構築した。

（2）油圧締め実験を行った結果，構築した解析手法や推定式により，数\%の誤差範囲内で精度良く有効軸力係数 が推定できることを確認した.

(3) 油圧締め解析により各種ボルト締結体の有効軸力係数を導出した結果, 植込みボルトが 0.780 , 通しボルトが 0.859, 両ナットボルトが 0.866 となった．また，各部のコンプライアンスを分析した結果，有効締付け長さ やかみ合い部のコンプライアンスの差異により, 植込みボルトと比較して, 両ナットボルトにおける油圧負 荷時のコンプライアンス合計值は 1.88 倍, 油圧開放時のコンプライアンス合計值は 1.68 倍となり, その結果 として，両ナットボルトの有効軸力係数が最も高くなることが分かった.

（4）フートをボルトに近接させる，あるいは，ボルト穴を 3 級から 1 級に縮小寸ることで，有効軸力倸数はそれ ぞれで約 $1 \%$ つ向上する. 植込みボルトで油圧締めした場合と比較して, 両ナットボルトに変更するととも に，フートをボルト穴に近接させ，かつ，ボルト穴を縮小寸ることで，有効軸力係数は約 $13 \%$ 向上できる.

\section{文献}

Fukuoka, T., Finite element simulation of tightening process of bolted joint with a tensioner, Transactions of the ASME, Journal of Pressure Vessel Technology, Vol.114 (1992), pp.433-438.

Fukuoka, T., Analysis of the tightening process of bolted joint with a tensioner using spring elements, Transactions of the ASME, Journal of Pressure Vessel Technology, Vol.116 (1994), pp.443-448.

福岡俊道，油圧テンショナを用いたボルト締付け法，機械設計，Vol.41, No.12 (1997), pp.79-85.

Fukuoka, T., Analysis of the tightening process of bolted joint with a tensioner, Transactions of the ASME, ASME DE, Vol.110 (2000), pp.119-125.

菅野裕嗣，永井照義，ボルトテンショナーによるボルト締付け試験，日本橋梁技報 (1998), pp.22-29.

黒沢亮, 永田聡, 沢俊行, 辰巳恭章, 内圧を受ける非石綿ガスケット付き箱型容器ボルト締結体の密封性能, 圧 力技術, Vol.47, No.1 (2009), pp.29-37.

Lori, W. and Glaser, H., Berechnung der plattennachgiebigkeit bei schraubenverbindungen, Konstruktion, Vol.46 (1990), pp.271-277（邦訳 : 賀勢晋司訳，㸚じ締結体における被締付け板のコンプライアンスの計算，日本ねじ研究 協会誌, Vol.22, No.12 (1991), pp.393-401).

丸井悦男, 橋本正俊, 加藤仁, 接触面剛性の評価法について, 精密工学会誌, Vol.59, No.7 (1993), pp.75-80. 
永田聡，松本光広，沢俊行，内圧作用下でのガスケット付管フランジ締結体の応力解析と密封性能評価，日本機 械学会論文集 A 編, Vol.70, No.699 (2004), pp.1595-1602.

中込昌孝，鈴木一郎，安田公輔，水野正夫，偏心外力を受ける衩じ締結体のコンプライアンスおよび内力係数に ついて，日本機械学会論文集 C 編，Vol.54, No.500 (1988), pp.960-967.

佐伯洋，ボルトテンショナーによる「軸力管理と注意点」，精密工学会誌，Vol.81, No.7 (2015), pp.633-637.

酒井智次，増補ねじ締結概論，第 10 版，養賢堂 (2009), pp.59-63.

丹野洋平, 成瀬友博, 橋本泰司, 油圧テンショナを用いたボルト締結体の軸力推定, 圧力技術, Vol.54, No.4 (2016), pp.170-180.

丹野洋平，成瀬友博，油圧テンショナによる繰返し締付け時のボルト軸力推定，圧力技術，Vol.56, No.1 (2018), pp.26-36.

Verein Deutscher Ingenieure, VDI 2230 Blatt 1, Systematic calculation of high duty bolted joints (1986)（邦訳：丸山一男， 賀勢晋司，沢俊行訳，高強度ねじ締結の体系的計算法，日本祇じ研究協会 (1989)).

Verein Deutscher Ingenieure, VDI 2230 Blatt 1, Systematic calculation of high duty bolted joints (2003)（邦訳 : 賀勢晋司, 川井謙一訳, 高強度ねじ締結の体系的計算法, 日本衩じ研究協会 (2006)).

\section{References}

Fukuoka, T., Finite element simulation of tightening process of bolted joint with a tensioner, Transactions of the ASME, Journal of Pressure Vessel Technology, Vol.114 (1992), pp.433-438.

Fukuoka, T., Analysis of the tightening process of bolted joint with a tensioner using spring elements, Transactions of the ASME, Journal of Pressure Vessel Technology, Vol.116 (1994), pp.443-448.

Fukuoka, T., Tightening process of bolted joint with a tensioner, Journal of the Nikkan Kogyo Shimbun, Machine Design, Vol.41, No.12 (1997), pp.79-85 (in Japanese).

Fukuoka, T., Analysis of the tightening process of bolted joint with a tensioner, Transactions of the ASME, ASME DE, Vol.110 (2000), pp.119-125.

Kanno, Y. and Nagai, T., Tightening test of bolted joint with a bolt tensioner, Journal of the Japan Bridge, Japan Bridge Technical Review (1998), pp.22-29 (in Japanese).

Kurosawa, R., Nagata, S., Sawa, T. and Tatsumi, Y., The sealing performance in flexible box-shaped flange bolted joints with non-asbestos compressed sheet gaskets subjected to internal pressure, Journal of the Japan High Pressure Institute, Pressure Engineering, Vol.47, No.1 (2009), pp.29-37 (in Japanese).

Lori, W. and Glaser, H., Berechnung der plattennachgiebigkeit bei schraubenverbindungen, Konstruktion, Vol.46 (1990), pp.271-277 (in German).

Marui, E., Hashimoto, M. and Kato, S., Estimation of Interface stiffness, Journal of the Japan Society for Precision Engineering, Vol.59, No.7 (1993), pp.75-80 (in japanese).

Nagata, S., Matsumoto, M. and Sawa, T., Stress analysis and sealing performance evaluation of pipe flange connections under internal pressure, Transactions of the Japan Society of Mechanical Engineers, Series A, Vol.70, No.699 (2004), pp.15951602 (in Japanese).

Nakagome, M., Suzuki, I., Yasuda, K. and Mizuno, M., On the compliance and the load factor of bolted connections subjected to eccentric loading, Transactions of the Japan Society of Mechanical Engineers, Series C, Vol.54, No.500 (1988), pp.960967 (in Japanese).

Saeki, H., Bolt fastening by bolt-tensioner, Journal of the Japan Society for Precision Engineering, Vol.81, No.7 (2015), pp.633637 (in Japanese).

Sakai, T., Outline of bolted joint (Enlarged edition), $10^{\text {th }}$ edition, Yokendo (2009), pp.59-63 (in Japanese).

Tanno, Y., Naruse, T. and Hashimoto, T., Estimation about axial tension of bolted joint by using hydraulic tensioner, Journal of the Japan High Pressure Institute, Pressure Engineering, Vol.54, No.4 (2016), pp.170-180 (in Japanese).

Tanno, Y. and Naruse, T., Estimation about bolt tension under repeated tightening by using hydraulic tensioner, Journal of the Japan High Pressure Institute, Pressure Engineering, Vol.56, No.1 (2018), pp.26-36 (in Japanese).

Verein Deutscher Ingenieure, VDI 2230 Blatt 1, Systematic calculation of high duty bolted joints (1986).

Verein Deutscher Ingenieure, VDI 2230 Blatt 1, Systematic calculation of high duty bolted joints (2003). 